REVIEW ARTICLE

\title{
Calcium and vitamin D supplementation: state of the art for daily practice
}

\author{
Robert Y. van der Velde ${ }^{*}$, Jacobus R. B. J. Brouwers², Piet P. Geusens ${ }^{3,4}$, \\ Willem F. Lems ${ }^{5}$ and Joop P. W. van den Bergh ${ }^{1,3,4}$ \\ 'Department of Internal Medicine, VieCuri Medical Centre for North Limburg, Venlo, The Netherlands; ${ }^{2}$ Department \\ of Geriatric Medicine, Expertise Centre for Pharmacotherapy in the Elderly, Ephor-UMC Utrecht, The Netherlands; \\ ${ }^{3}$ Department of Rheumatology, CAPHRI, Maastricht UMC, Maastricht, The Netherlands; ${ }^{4}$ Biomedical Research \\ Centre, University of Hasselt, Diepenbeek, Belgium; ${ }^{5}$ Department of Rheumatology, VU Medical Centre, Amsterdam, \\ The Netherlands
}

Abstract

Background: Calcium and vitamin D play an essential role in bone metabolism but deficiency and/or inadequate intake are common.

Objectives: To describe a practical approach based on the literature regarding clinically important aspects of calcium and vitamin D supplementation.

Methods: A systematic evaluation of relevant literature in Medline was conducted. We included physiological studies, publications on relevant guidelines, meta-analysis, randomized clinical trials, and cohort studies.

Results: An adequate calcium intake and vitamin D supplementation is recommended in most guidelines xon fracture prevention. Daily supplementation with $800 \mathrm{IU}$ is advocated in most guidelines, appears to be safe, and with this approach it is generally not necessary to determine vitamin D levels. There are no data on additional effects of loading doses of vitamin D on fracture or fall prevention. Calcium supplementation should be tailored to the patient's need: usually $500 \mathrm{mg}$ per day is required. The intestinal absorption of calcium citrate is approximately $24 \%$ better than that of calcium carbonate independent of intake with meals. Data on difference between calcium absorption with calcium carbonate compared to calcium citrate with simultaneous use of proton pump inhibitors are lacking. Concern has arisen about a possible link between calcium supplementation and an increased risk of myocardial infarction. Probably only well-designed prospective randomized controlled trials will be able to allow definite conclusions on this subject.

Conclusion: Daily supplementation with $800 \mathrm{IU}$ vitamin D is a practical and safe strategy without the need for prior determination of vitamin D levels. Calcium supplementation should be tailored to the patient's need based on total daily dietary calcium intake. In most patients $500 \mathrm{mg}$ per day is required to achieve a total intake of $1,200 \mathrm{mg}$, or in some $1,000 \mathrm{mg}$ per day. More calcium is absorbed from calcium citrate compared to calcium carbonate.

Keywords: calcium absorption; vitamin D supplementation; fracture prevention; fall prevention; cardiovascular risk

Received: 19 June 20 I4; Revised: 24 June 20।4; Accepted: I July 20।4; Published: 7 August 20I4

$\mathrm{T}$ he essential role of calcium for bone metabolism has been known since the animal studies (in 1928) and calcium balance studies (in 1946) performed by Albright (1). Rickets was first described more than 300 years ago (Glisson, 1599-1677), but the essential role of vitamin D with regards to bone metabolism only became clear following animal experiments with liver oil supplements by McCollum (2).

Vitamin D supplements reduce the risk of falls and fractures in vitamin D-deficient subjects. Vitamin D deficiency is worldwide considered endemic and therefore vitamin D supplementation is recommended in most guidelines on fracture prevention.

Inadequate intake of calcium via the diet is also common, even more so in patients with a recent fracture, and adequate calcium intake is recommended in the guidelines. The absorption of calcium from the intestines occurs by means of an active, vitamin D-dependent process and to a lesser extent by passive diffusion and is determined - among other factors - by the solubility of 
calcium and the $\mathrm{pH}$ in the different parts of the gastrointestinal system. Observational research indicates that excessive calcium intake could increase the risk of cardiovascular events.

In daily practice, the care of adequate calcium homeostasis will depend on the need of vitamin D and calcium. There are, however, few all-encompassing studies available about the relationship between the dosage of vitamin $\mathrm{D}$ supplementation and changes in serum $25(\mathrm{OH}) \mathrm{D}$ to answer questions about the need amongst the elderly, the target values for serum levels, and the quantity and frequency of vitamin D supplements. For calcium intake, the question that arises is what the minimum and maximum calcium dosages should be for recommendation.

This overview aims to provide an answer to these questions, based on a review of relevant literature.

\section{Calcium and vitamin $D$ recommendations in} Guidelines on Osteoporosis and Fracture Prevention The 2011 Dutch Guideline on Osteoporosis and Fracture Prevention (CBO Guideline) advises in the case of patients taking medication to prevent fractures to aim for a total calcium intake (diet and supplements) of 1,000$1,200 \mathrm{mg}$ calcium per day and an intake of vitamin D supplements of $800 \mathrm{IU}$ per day (3).

The United Kingdom NICE 2012 guidelines on fractures and osteoporosis, that are mainly focused on fracture risk and other related NICE guidelines, have no special focus on calcium and vitamin D (http://www. nice.org.uk/nicemedia/live/13857/60399/60399.pdf) (last assessed on April 24, 2013). A new guideline on vitamin D will be available in 2014. Canadian guidelines (4) advise intake of $1,200 \mathrm{mg}$ calcium daily in women 50 years and older and men 70 years and older. The vitamin D intake in elderly persons should be 1,0001,200 IU daily. The Australian guideline (http://www. osteoporosis.org.au/images/stories/updatedthinkgp.pdf) (last assessed on April 24th 2013) advises for women over 50 years of age a calcium intake of $1,300 \mathrm{mg}$ per day and a vitamin $\mathrm{D}$ intake of 800 IE. In the international literature, there is no consensus on the daily vitamin D supplementary intake (5).

In a recent statement, the US Preventive Services Task Force (USPSTF) recommends against daily supplementation with $400 \mathrm{IU}$ or less of vitamin D and $1,000 \mathrm{mg}$ or less of calcium for the primary prevention of fractures in non-institutionalized post-menopausal women (6). The USPSTF concludes that the current evidence is insufficient to assess the balance of the benefits and harms of daily supplementation with greater than 400 IU of vitamin D and greater than 1,000 $\mathrm{mg}$ of calcium for the primary prevention of fractures in the same population (6).
Meta-analyses reveal that calcium supplementation reduces the risk of non-vertebral fractures, with the effect being amplified in combination with vitamin $\mathrm{D}(7,8)$, particularly for hip fracture reduction (9). Supplementation of 400-1,200 IU of vitamin D per day for the elderly ( $>65$ years), in combination with calcium, results in a relative reduction of the occurrence of non-vertebral fractures of $10-20 \%(10,11)$.

An association between vitamin D deficiency, falls, and fracture rates in older women and men has been demonstrated in several studies (12-14).

In a 1-year randomized, population-based, controlled trial 1,000 IU of daily oral ergocalciferol treatment reduced the risk of falling over a year by about onethird in women with a serum 25 hydroxyvitamin D $(25 \mathrm{OHD})<60 \mathrm{nmol} / \mathrm{L}$ and a history of falls in the previous year (15).

In all randomized clinical trials on the effect of drugs with fracture prevention as primary endpoint, both the intervention group and the placebo group were supplemented with vitamin D and calcium (Table 1). However, there were large differences in the amount of calcium and vitamin D supplements in the various fracture studies.

Most of these studies were performed with standard dosages of 250-1,200 IU/ day for vitamin D and 500$1,000 \mathrm{mg}$ per day for calcium or dosages of calcium and vitamin D supplements adjusted for dietary intake and serum values of $25(\mathrm{OH}) \mathrm{D}$. In some studies, vitamin $\mathrm{D}$ supplements were given before the start of the study, in daily doses during several weeks to months, or in bolus up to $125,000 \mathrm{IU}$.

\section{Mechanism and functional aspects of intestinal absorption of the calcium salts}

The intestinal calcium absorption has been studied extensively in balance studies in patients with chronic renal insufficiency, revealing that a dietary intake of $1,000 \mathrm{mg}$ calcium results in approximately $400 \mathrm{mg}$ being absorbed in the digestive tract, whilst $200 \mathrm{mg}$ of calcium is added to the intestinal lumen via excretion. The total amount of calcium that passes the digestive tract is therefore $1,200 \mathrm{mg}$, of which $800 \mathrm{mg}$ is excreted via the feces. This means that the average fractional calcium absorption is $400 / 1,200=0.33(16,17)$. The serum calcium level and the 24-h calcium excretion can be measured accurately in clinical practice, but the actual quantity of calcium that is absorbed by the bones is much more difficult to measure. This requires the use of 'bio-markers', absorption of calcium isotopes, or - after extended treatment - bone densitometry. The absorption of calcium occurs primarily in the small intestine via an active trans-cellular process on the one hand, regulated by active vitamin $\mathrm{D}\left(1.25(\mathrm{OH})_{2} \mathrm{D}_{3}\right)$, and via para-cellular diffusion on the other hand $(18,19)$, the latter being 
Table 1. Calcium and vitamin D supplementation in medicinal fracture intervention studies

\begin{tabular}{|c|c|c|c|}
\hline Study & Medicine & Calcium, mg/d & Vitamin $D, I E / d$ \\
\hline Black 1996 & Alendronate & 500 when required & 250 \\
\hline Cummings 1996 & Alendronate & 500 when required & 250 \\
\hline Harris 1999 & Risedronate & 1,000 & 500 when required $^{\mathrm{a}}$ \\
\hline Reginster 2000 & Risedronate & 1,000 & 500 when required $^{\mathrm{a}}$ \\
\hline McClung 200I & Risedronate & 1,000 & 500 when required $^{\mathrm{a}}$ \\
\hline Chestnut 2004 & Ibandronate & 500 & 400 \\
\hline Black 2007 & Zoledronate & $1,000-1,500$ & $400-1,200$ \\
\hline \multirow[t]{3}{*}{ Lyles 2007} & Zoledronaat hip & $1,000-1,500$ & $25(\mathrm{OH}) \mathrm{D}<37.5 \mathrm{nmol} / \mathrm{L}$ or not measured: \\
\hline & & & Loading dose: $50-120,000$ \\
\hline & & & Thereafter $800-1,200$ \\
\hline Ettinger & Raloxifen & 500 & $400-600$ \\
\hline Neer 200I & Teriparatide & 1,000 & $400-1,200$ \\
\hline Greenspan 2007 & PTH & 700 & 400 \\
\hline Meunier 2004 & SR*SOTI & $0-1,000^{\mathrm{b}}$ & $400-800$ \\
\hline Reginster 2005 & SR*TROPOS & $0-1,000^{b}$ & $400-800$ \\
\hline \multirow[t]{3}{*}{ Cummings } & Denosumab & 1,000 & $25(\mathrm{OH}) \mathrm{D} \mathrm{nmol} / \mathrm{L}:$ \\
\hline & & & $30-50: 800$ \\
\hline & & & $>50: 400$ \\
\hline
\end{tabular}

${ }^{\mathrm{a}}$ If the vitamin $\mathrm{D}$ level was lower than $40 \mathrm{nmol} / \mathrm{L}$.

${ }^{\mathrm{b}}$ To achieve a total intake of I,000 $\mathrm{mg}$ per day.

$\mathrm{SR}^{*}$, strontium ranelate.

largely vitamin D independent. The active transport is a process that can become saturated and is particularly important in the event of limited calcium intake. This results in an upregulation of the production of active vitamin D. As the fractional calcium absorption is significantly determined by active vitamin $\mathrm{D}$, vitamin $\mathrm{D}$ deficiency will also result in decreased calcium absorption. Heaney et al. demonstrated that the calcium absorption increases up to a serum $25(\mathrm{OH}) \mathrm{D}$ level of $80 \mathrm{nmol} / \mathrm{L}$ and reaches a plateau at $>80 \mathrm{nmol} / \mathrm{L}$ (Fig. 1) (20). Assuming the fact that approximately $35 \%$ of the available calcium is absorbed in the gastrointestinal system, the question is how significant the contributions of the active and passive transport systems are and in which parts of the gastrointestinal system this absorption occurs.

The course of calcium absorption and, in particular, the contribution of active and passive absorption of calcium over the course of the jejunum, ileum, and colon is presented in Fig. $2(19,21)$.

The solubility of the type of calcium salts is important for this absorption process, because calcium can only be absorbed in dissolved form $(24,25)$. However, the solubility of calcium is primarily dependent on $\mathrm{pH}$, so that the $\mathrm{pH}$ of the digestive tract is an important factor in this absorption process. In addition, factors such as $\mathrm{pCO}_{2}$ and the quantity of bicarbonate and phosphate play an additional role in the calcium absorption process. It is known that the $\mathrm{pH}$ changes over the course of the digestive tract: very low in the stomach ( $\mathrm{pH} 1-2)$, approximately $\mathrm{pH} 6$ in the duodenum, gradually increasing in the small intestine from 6 or 6.5 in the proximal jejunum to 7.4 in the middle of the small intestine and to 7.5 in the ileum. The $\mathrm{pH}$ then decreases to 6.4 in the cecum and in the course of the colon gradually increases again to 6.7 and finally to 7 in the rectum (Fig. 2) $(22,26)$. The average $\mathrm{pH}$ is 7.3 in the small intestine and 6.6 in the colon (23).

In this context, it is important to realize that calcium is not absorbed in the stomach, but in the small and large intestine. The total amount of calcium that is absorbed

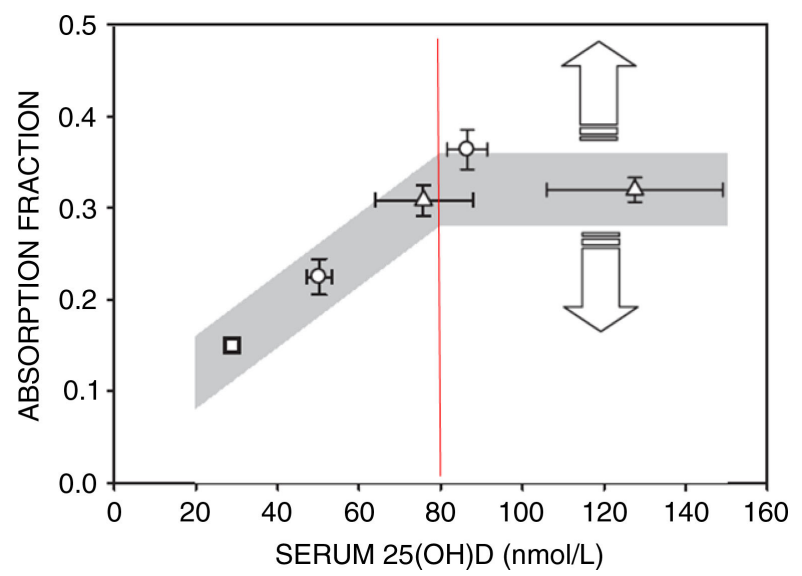

Fig. 1. Relationship between serum 25(OH)D level and fractional calcium absorption (20). 


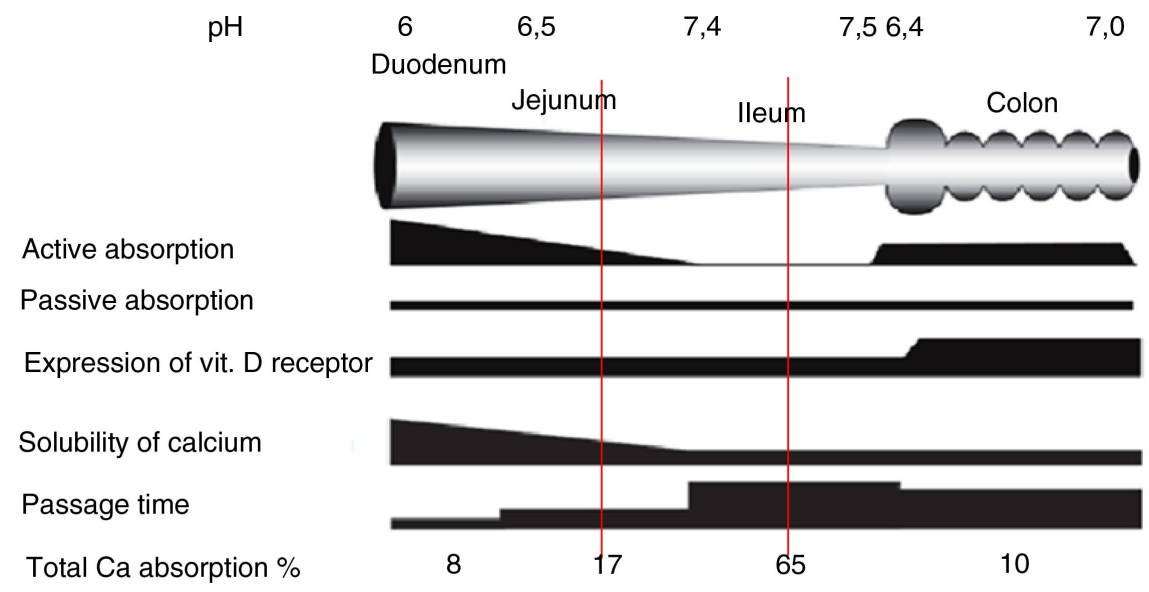

$65 \%$ of the total calcium absorption takes place in the ileum (between the red lines).

Fig. 2. Calcium absorption, solubility of calcium, contribution of active and passive absorption of calcium and $\mathrm{pH}$ in the various segments of the small and large intestine $(19,22,23)$.

therefore depends on the amount of calcium consumed, the passage time in the various segments of the small and large intestine, and the amount of soluble calcium available for absorption, which is primarily determined by the $\mathrm{pH}$ in each segment of the gastrointestinal tract. In the duodenum, and to a lesser extent the jejunum, there is active calcium transport in addition to passive transport; in the ileum there is primarily passive transport. The largest quantity, namely $65 \%$ of the absorbed calcium, is absorbed via passive transport in the ileum, because of the length of this segment compared to the other parts of the digestive tract $(19,21)$.

Calcium supplementation usually happens as a calcium salt in the form of calcium carbonate or calcium citrate. There are several calcium compounds available. When a compound containing calcium carbonate is taken, this is dissolved in the acidic environment of the stomach. When a compound which contains calcium carbonate and citric acid is taken then this will form calcium citrate when dissolved in a glass of water. These various calcium compounds are also available in various combination preparations with low - 400/440 IU - and higher - 800/ $880 \mathrm{IU}$ - dosages of vitamin D.

The solubility of these salts has been tested in water, showing that calcium citrate dissolved more completely than calcium carbonate. However, dissolving calcium citrate results in a $\mathrm{pH}$ of 5.6 and calcium carbonate in a $\mathrm{pH}$ of 8.5 , neither of which is an accurate reflection of solubility in the digestive system. After all, the $\mathrm{pH}$ varies per section of the digestive system and therefore the solubility of the calcium salt will also vary per section (27-29).

When the calcium salts are ingested and enter the acidic environment of the stomach, dissolved calcium ions become available (30).

\begin{tabular}{llll}
\hline $\mathrm{CaCO}_{3}$ (insoluble) & $+2 \mathrm{HCl}$ & $\rightarrow \mathrm{Ca}^{2+}+2 \mathrm{Cl}^{-}+\mathrm{H}_{2} \mathrm{O}+\mathrm{CO}_{2}$ \\
Calcium carbonate & Hydrochloric $\rightarrow$ & Soluble calcium ion \\
& acid & & Carbon dioxide \\
$\mathrm{Ca}_{3}\left(\mathrm{C}_{6} \mathrm{H}_{5} \mathrm{O}_{7}\right)_{2} \cdot 4 \mathrm{H}_{2} \mathrm{O}+6 \mathrm{HCl}$ & $\rightarrow \begin{array}{l}2 \mathrm{C}_{6} \mathrm{H}_{5} \mathrm{O}_{7}^{3-}+6 \mathrm{H}^{+}+3 \mathrm{Ca}^{2+} \\
+6 \mathrm{Cl}^{-}+4 \mathrm{H}_{2} \mathrm{O}\end{array}$ \\
Calcium citrate & Hydrochloric $\rightarrow$ & Citric acid \\
& acid & & Soluble calcium ion \\
& & &
\end{tabular}

An increasing $\mathrm{pH}$ in the duodenum and jejunum (due to bicarbonate production) will result in decreased solubility of calcium because calcium salts are formed once more:

$\mathrm{CaCl}_{2}+2 \mathrm{NAHCO}_{3} \rightarrow \mathrm{CaCO}_{3}+2 \mathrm{NaCl}+\mathrm{CO}_{2}+\mathrm{H}_{2} \mathrm{O}$

In vitro study of the $\mathrm{pH}$-dependent solubility of calcium carbonate compared to calcium citrate - taking into consideration the $\mathrm{CO}_{2}$ tension that affects the solubility in the digestive tract - shows that the solubility of carbonate is higher at a $\mathrm{pH}<6.5$ and the solubility of the citrate form is higher at $\mathrm{pH}>6.5$ (Fig. 3). At a pH of 7.5, the solubility of citrate is around two times higher than that of carbonate. However, the solubility of both calcium salts decreases with increasing $\mathrm{pH}(27-29)$.

If we translate this to the practical setting, there are two clinical questions that need to be asked: Is the calcium absorption with use of a calcium-containing supplement the same for calcium carbonate and calcium citrate? and Does the absorption of calcium carbonate and calcium citrate differ in the event of a (relative) high stomach $\mathrm{pH}$, as is the case with the use of antacids or hypochlorhydria or achlorhydria? 


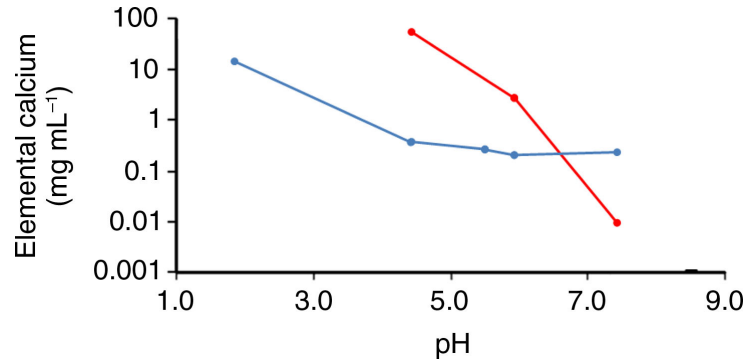

Fig. 3. Concentration of dissolved elemental calcium (Y-axis, log scale) depending on $\mathrm{pH}$ for calcium citrate (blue line) and calcium carbonate (red line), corrected for $\mathrm{CO}_{2}$ tension in the digestive tract. Modified from Goss et al. (29).

Based on these in vitro models, the stomach $\mathrm{pH}$ does have an effect on the solubility of the various calcium salts, but because absorption occurs primarily in the small and large intestine - particularly the ileum at a $\mathrm{pH}$ of around 7.5 (Fig. 2: $\pm 65 \%$ of the total calcium absorption) it could well be that the $\mathrm{pH}$ of the stomach is far less relevant and that the solubility of the calcium salt in the $\mathrm{pH}$ range of 6.5 to 7.5 is of particular importance. Of course, the fact that the in vitro models do not correct for other factors, such as buffering by amino acids, bile, and food components, should be taken into consideration (27-29).

The difference in calcium absorption with supplementation of calcium carbonate compared to calcium citrate has been studied extensively. A meta-analysis was published by Sakhaee et al. in 1999, which concluded that calcium absorption was (statistically significant) 24\% higher in cases of supplementation with calcium citrate compared with calcium carbonate, both when taken on an empty stomach and when ingested during a meal (Table 2, upper portion) (31). A number of studies have been published since 1999 about this subject, using various techniques to determine calcium absorption, usually in healthy study subjects or post-menopausal women and applying various calcium dosages. The data of these studies are presented in Table 2, lower portion.

The influence of achlorhydria and proton pump inhibitors on calcium absorption Literature about the presence of achlorhydria in the elderly is limited. A systematic review by Hurwitz et al. (40)

Table 2. Clinical studies into the effect of intestinal calcium absorption with the use of calcium citrate versus calcium carbonate: the upper portion lists the studies in the meta-analysis by Sakhaee et al. (31) and the lower portion lists the studies published thereafter

\begin{tabular}{|c|c|c|c|c|c|c|c|c|}
\hline Author & Year & $N$ & Gender & Population & Method & Calcium dosage (mg) & Meal & Effect citrate vs. carbonate (\%) \\
\hline Bo-Linn & 1984 & 6 & & Normal & Lavage & 1,000 & + & 21.6 \\
\hline Nicar & 1985 & 14 & II f, $3 \mathrm{~m}$ & Normal & Urine $\mathrm{Ca}$ excretion & 1,000 & - & 70.5 \\
\hline Recker & 1985 & 7 & & Normal & Dual isotope & 250 & - & 8.0 \\
\hline Reid & 1986 & 10 & & Normal & Urine $\mathrm{Ca}$ excretion & 1,000 & + & 64.8 \\
\hline Smith & 1987 & 10 & $f$ & Normal & Dual isotope & 250 & + & 26.0 \\
\hline Harvey & 1988 & 9 & & Normal & Faecal recovery & 100 or 200 & - & 28.0 \\
\hline Miller & 1988 & 12 & & Children & Dual isotope & 250 & + & 36.9 \\
\hline Sheikh & 1989 & 10 & & Normal & Lavage & 1,000 & + & 4.8 \\
\hline Harvey & 1990 & 20 & $f$ & & Dual isotope & 500 & - & 25.8 \\
\hline Harvey & 1998 & 21 & $17 \mathrm{f}, 4 \mathrm{~m}$ & & Urine $\mathrm{Ca}$ excretion & 1,000 & - & 55.7 \\
\hline Heaney & 1999 & 17 & $f$ & Pre-men & Serum radioactivity & 300 & + & 10.8 \\
\hline \multirow[t]{2}{*}{ Sakhaee } & 1999 & & & & Meta-analysis & & & $24 \%$ pooled effect \\
\hline & & & & & & & & Effect citrate vs. carbonate \\
\hline Micheletti (32) & 1996 & 14 & & & Dual isotope & $\mathrm{I} \times \mathrm{I}, 000$ vs. $2 \times 500$ & - & $\mathrm{Ca}>\mathrm{Ci}$ \\
\hline Heller (33) & 1999 & 18 & $f$ & Post-men & Serum $\mathrm{Ca}, \mathrm{AUC} \mathrm{Ca}$ & 500 & + & $\mathrm{Ci}>\mathrm{Ca}$ \\
\hline Heller (34) & 2000 & 25 & $\mathrm{f}$ & Post-men 61 & $\begin{array}{l}\text { Serum } \mathrm{Ca}, \mathrm{AUC} \mathrm{Ca}, \mathrm{PTH} \\
\text { urine } \mathrm{Ca}\end{array}$ & 500 & + & $46-94$ \\
\hline Heaney (35) & 2001 & 24 & $f$ & Post-men 58 & $\begin{array}{l}\text { AUC serum } \mathrm{Ca}, \mathrm{PTH} \text {, urine } \\
\text { Ca excretion }\end{array}$ & 200 & + & n.s. \\
\hline Kenny (36) & 2004 & 34 & $f$ & & $\begin{array}{l}\text { PTH, BSAP, urine Ca excretion, } \\
\text { CTX, NTX }\end{array}$ & I,000 mg I2 week co & + & $\mathrm{Ci}>\mathrm{Ca}(\mathrm{CTX}, \mathrm{NTX})$ \\
\hline Hanzlik (37) & 2005 & 14 & $f$ & $19-33$ & AUC Ca, PTH & 1,200 & - & $\mathrm{Ci}>\mathrm{Ca}$ \\
\hline Thomas (38) & 2008 & 25 & $f$ & Post-men & PTH, CTX & $500 \mathrm{Ci}$ and $\mathrm{I}, 000 \mathrm{Ca}$ & - & $\mathrm{Ci}>\mathrm{Ca}$ \\
\hline Karp (39) & & 12 & $f$ & $22-30$ & BSAP, serum Ca, PTH & 1,000 & + & - \\
\hline
\end{tabular}

$\mathrm{F}=$ female, $\mathrm{m}=$ male, pre-men $=$ pre-menopausal, post-men $=$ post-menopausal, $n . s .=$ not significant, $\mathrm{AUC}=$ area under the curve, $\mathrm{BSAP}=$ bone-specific alkaline phosphatase. 
shows that only $11 \%$ of people older than 65 had a consistent stomach $\mathrm{pH}$ of $>3.5$ at two consecutive measurements and $67 \%$ had a consistently low $\mathrm{pH}$. A varying stomach $\mathrm{pH}$ (one time $>3.5$ and one time $<3.5)$ was found in $22 \%(40)$. The effect of achlorhydria on the absorption of calcium with the use of various supplements has not been studied in any detail.

The effect of proton pump inhibitors on calcium absorption was studied in a review in 2008 (41). This reveals that varying and small groups of patients were studied, using different methods to evaluate calcium absorption and that a reliable answer cannot currently be provided on the question whether the use of antacids has a detrimental effect on calcium absorption (41). The most recent article on this issue was a randomized trial published in 2010 by the same author and revealed no difference in intestinal calcium absorption between $20 \mathrm{mg}$ esomeprazole per day and placebo (42). There has been no research to determine whether there is a difference in calcium absorption between the various calcium salts with use of proton pump inhibitors. Furthermore, the conclusion in the CBO Guideline is that evidence based on observational research suggesting that protonpump inhibitor (PPIs) are fracture-inducing medicines is very weak, particularly as this association can also be linked to the diseases for which the PPIs are prescribed $(3,43)$.

In conclusion, the in vitro data and models are complex and do not entirely explain the calcium absorption process in vivo. Clinical studies point consistently to better absorption of calcium with use of citrate than with carbonate. This difference appears to be explained by a higher passive transport of calcium, because in the ileum - where $65 \%$ of calcium is absorbed by means of passive transport - calcium citrate dissolves better than calcium carbonate at a $\mathrm{pH} \geq 7.5$. Studies on the effect of proton pump inhibitors on the absorption of calcium are not unanimous in conclusion and have poor methodology, any differences between calcium citrate and calcium carbonate in this regard were not studied.

\section{How much calcium and vitamin D should be prescribed?}

The average calcium intake in Great Britain for postmenopausal women is $645-705 \mathrm{mg}$ calcium per day (44). This figure is $720-820 \mathrm{mg}$ calcium per day in Germany (45) and in France (46). The calcium intake was also studied in the Netherlands: one-third of the women in a study performed in Amsterdam consumed less than $950 \mathrm{mg}$ calcium per day (47); 18\% of the women of approximately the same age in a more rural area (Ede, the Netherlands) consumed less than $800 \mathrm{mg}$ per day (48). In a population with an average age of 80 years, living independently or in care homes, $25 \%$ consumed less than $938 \mathrm{mg}$ per day (49). This shows that there is a large variation in the average calcium intake between the different countries. In addition, there is a large variation between individuals. It is particularly important to know what the calcium intake is of those individuals who are most in need of supplementation, for example, the patients with a recent fracture. This was demonstrated recently in a study in 502 patients over the age of 50 years with a recent fracture: only $11 \%$ had a calcium intake $>1,000 \mathrm{mg}$ per day in combination with serum $25(\mathrm{OH}) \mathrm{D}$ levels $>50 \mathrm{nmol} / \mathrm{L}$ (Fig. 4) (50). An excessively low serum vitamin $\mathrm{D}$ level in combination with inadequate calcium intake occurred in $43 \%$ (50).

As demonstrated in Fig. 5, this shortage applies to both men and women, in all examined age categories $>50$ years and with all types of fractures. It is noteworthy that the inadequate calcium intake occurred in equal measures with a normal BMD, osteopenia, and osteoporosis. Therefore, inadequate calcium intake is an endemic problem in patients presenting with a fracture (50). Based on these data, one can conclude that one should check the calcium intake and vitamin D level in all fracture patients, even in those with a normal BMD.

\section{Required calcium supplementation}

Recently, the required calcium supplementation was studied in patients with a recent fracture $(50,51)$. In order to guarantee calcium intake of 1,000 per day, $12 \%$ of patients required supplementation of $1,000 \mathrm{mg}$ per day and $57 \%$ required $500 \mathrm{mg}$. If one were to prescribe $500 \mathrm{mg}$ calcium supplementation per day to all patients for pragmatic reasons, this would only be inadequate for achieving the required total intake of $1,000 \mathrm{mg}$ per day in $12 \%$ of the patients, whilst only a very small group of patients achieves an unnecessary daily calcium intake $>1,500 \mathrm{mg}$. If one were to prescribe a standard $1,000 \mathrm{mg}$ calcium supplementation per day, nearly $90 \%$ would exceed the limit of $1,500 \mathrm{mg}$ per day. Except for a small group requiring $1,000 \mathrm{mg}$ per day because they consume virtually no dairy products, $1,000 \mathrm{mg}$ supplementation is too high a level of substitution, particularly in the light of indications about the potentially negative cardiovascular effects of high-dose calcium supplementation.

With the use of corticosteroids, there are many factors that play a role in increasing the risk of osteoporosis and fractures. One of these is the reduced intestinal absorption of calcium. A higher level of calcium intake is therefore required. All studies in patients treated with corticosteroids gave supplementation of 1,000-1,500 mg calcium per day, which is more than the recommended supplementation dose for post-menopausal women and age-related osteoporosis.

\section{Required vitamin D supplementation}

Dawson-Hughes et al. reported an estimated average essential vitamin D intake of $800-1,000$ IU per day (20$25 \mu \mathrm{g}$ per day) in order to achieve a $25(\mathrm{OH}) \mathrm{D}>75 \mathrm{nmol} / \mathrm{L}$ 


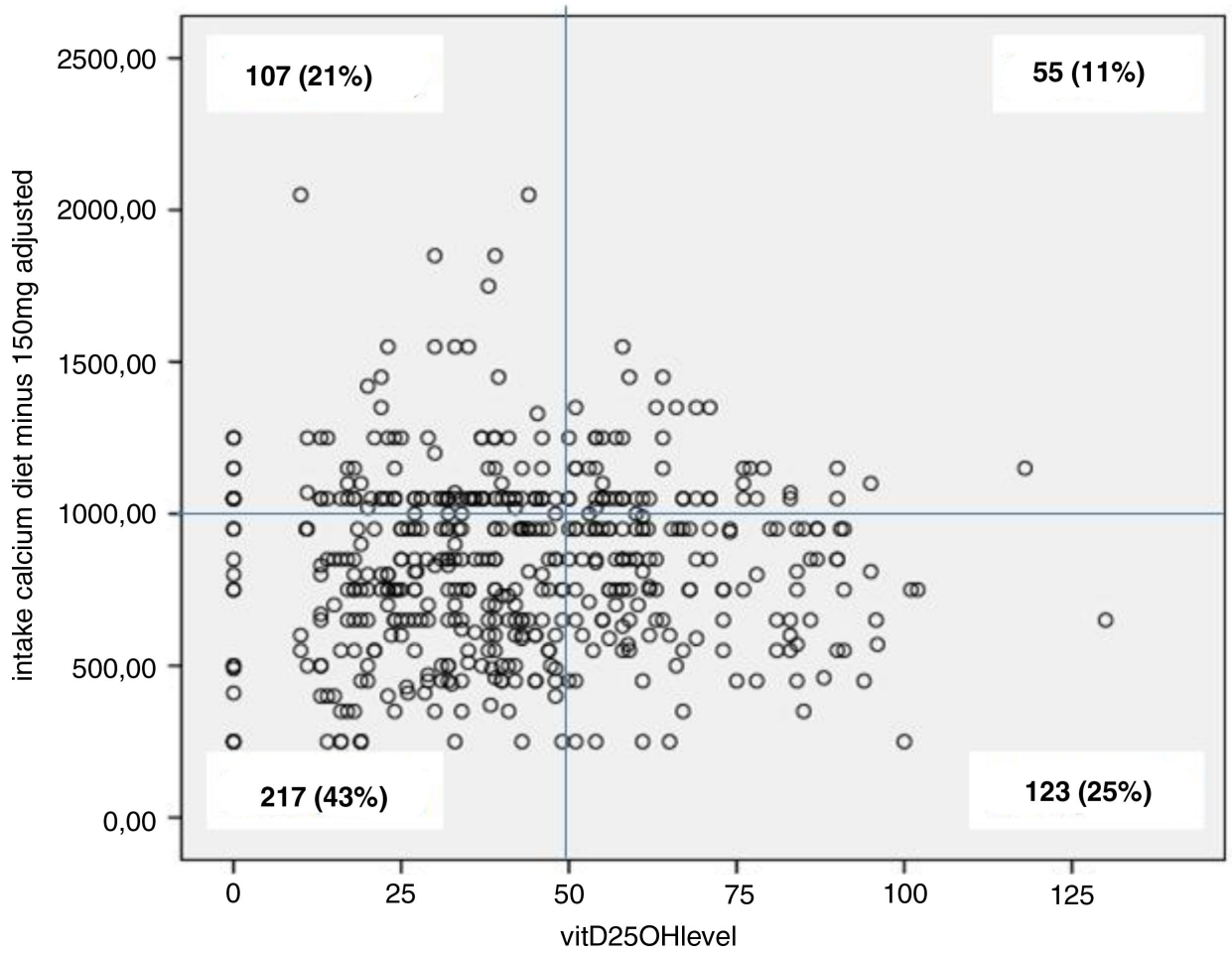

Fig. 4. Calcium intake and serum $25(\mathrm{OH}) \mathrm{D}$ in $50+$ patients with a recent fracture.

in the elderly. Significantly higher dosages are required to ensure that virtually all elderly people achieve this level of vitamin D (52). However, there are no arguments for dosages higher than $800 \mathrm{IU}$ per day $(20 \mu \mathrm{g}$ per day), because there are not enough studies to support this. Cranney et al. performed a meta-analysis in 2007 on the relationship between serum $25(\mathrm{OH}) \mathrm{D}$ and the intake of vitamin $\mathrm{D}$ form the diet. The conclusion of this study was

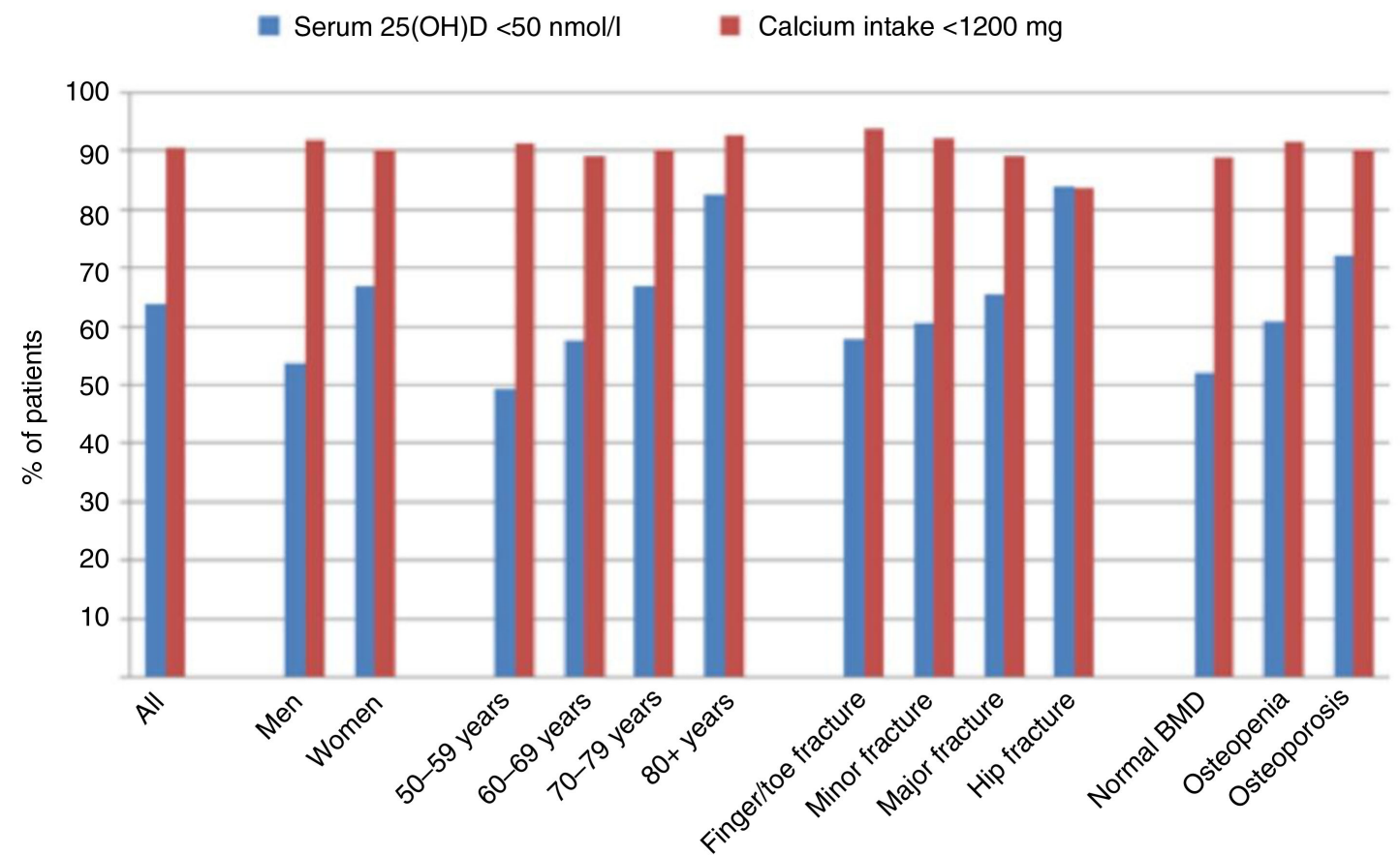

Fig. 5. Calcium intake and serum $25(\mathrm{OH}) \mathrm{D}$ in $50+$ patients with a recent fracture, according to gender, age, fracture location and BMD. 
that vitamin $\mathrm{D}$ in the diet increased the serum $25(\mathrm{OH}) \mathrm{D}$ concentration, but it was not clear to which extent. The large discrepancies between the various studies (differences in initial vitamin D levels, different populations, different assays for vitamin $\mathrm{D}$, etc.) made it impossible to indicate how much vitamin $\mathrm{D}$ is required for whom (53).

Studies by Heaney (54) show that every 100 IU added vitamin D causes the serum $25(\mathrm{OH}) \mathrm{D}$ level to increase by $2.5 \mathrm{nmol} / \mathrm{L}$ (range $1.75-2.75 \mathrm{nmol} / \mathrm{L}$ ). Therefore, a dosage of $800 \mathrm{IU}$ will cause an increase in serum $25(\mathrm{OH}) \mathrm{D}$ of approximately $20 \mathrm{nmol} / \mathrm{L}$.

Based on the $25(\mathrm{OH}) \mathrm{D}$ levels in a study of 626 patients with a recent fracture, one could theoretically - going out from the starting point that every $100 \mathrm{IU}$ of added vitamin D causes a $2.5 \mathrm{nmol} / \mathrm{L}$ increase in the serum $25(\mathrm{OH}) \mathrm{D}$ level - tailor the vitamin D supplementation in order to achieve a level $\geq 50 \mathrm{nmol} / \mathrm{L}$ in everyone (55) (Fig. 6).

In order to achieve a level $\geq 75 \mathrm{nmol} / \mathrm{L}$ in every patient, one would theoretically have to give a dosage $>800 \mathrm{IU}$ per day to at least $80 \%$ of the patients, even up to $2,400 \mathrm{IU}$ per day (Fig. 6).

\section{Serum 25(OH)D}

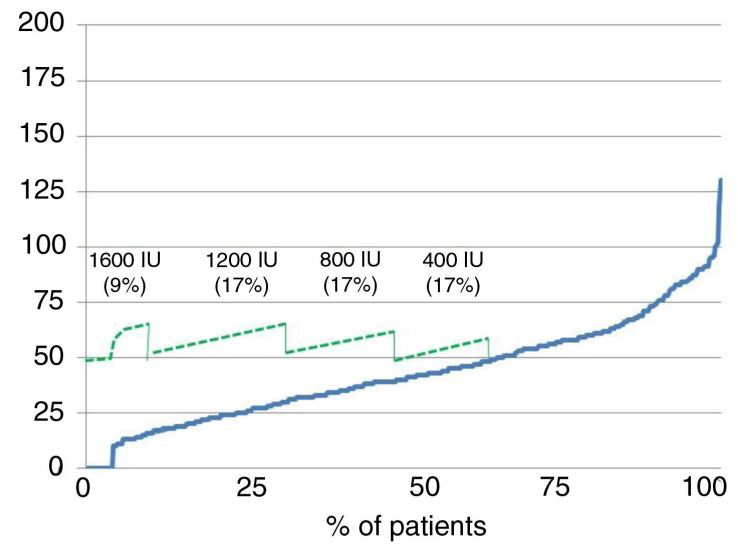

Serum 25(OH)D

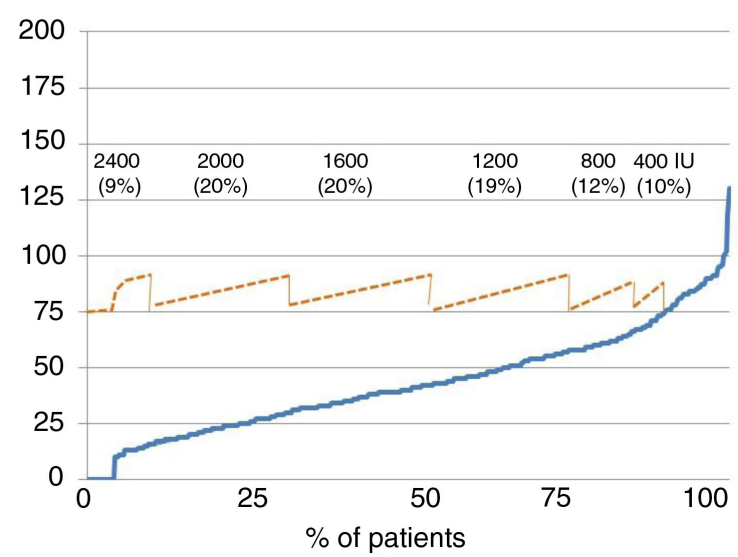

Fig. 6. Required dose of vitamin D to achieve a $25(\mathrm{OH}) \mathrm{D}$ level: $\geq 50$ (top panel) and $\geq 75 \mathrm{nmol} / \mathrm{L}$ (bottom panel).
If one assumes a standard supplementation of $800 \mathrm{IU}$ vitamin $\mathrm{D}_{3}$, this will achieve a $25(\mathrm{OH}) \mathrm{D} \geq 50 \mathrm{nmol} / \mathrm{L}$ in $75 \%$ of the patients (Fig. 7).

A standard supplementation of 2,000 IU vitamin $\mathrm{D}_{3}$ would theoretically result in a $25(\mathrm{OH}) \mathrm{D} \geq 50 \mathrm{nmol} / \mathrm{L}$ in $100 \%$ of the patients and a $25(\mathrm{OH}) \mathrm{D} \geq 75 \mathrm{nmol} / \mathrm{L}$ in $90 \%$ of the patients (Fig. 7).

In addition, there are as yet unidentified sub-groups that require higher dosages of vitamin $\mathrm{D}_{3}$, such as patients with a severe vitamin $\mathrm{D}$ deficiency with secondary hyperparathyroidism. The first placebo-controlled study on the effect of various daily dosages of vitamin $\mathrm{D}_{3}$ in healthy post-menopausal women with vitamin $\mathrm{D}$ deficiency $(25(\mathrm{OH}) \mathrm{D}<50 \mathrm{nmol} / \mathrm{L})$ was published very recently. The authors concluded that a dosage of $800 \mathrm{IU}$ per day resulted in an increase of the serum 25(OH)D level to above $50 \mathrm{nmol} / \mathrm{L}$ in $97.5 \%$ of the women, without further increase after 12 months. These results show that a daily dosage of $800 \mathrm{IU}$ is sufficient for the majority of post-menopausal women with vitamin $\mathrm{D}$ deficiency to exceed the threshold of $50 \mathrm{nmol} / \mathrm{L}$, which most guidelines consider the desired threshold value of $25(\mathrm{OH}) \mathrm{D}(56)$.

\section{Calcium intake and cardiovascular disease}

Concern has arisen amongst doctors and patients following the epidemiological study by Bolland et al. from 2008 (57). This study found a link between calcium supplementation and an increased risk of myocardial infarction. This study evaluated healthy elderly women who - in addition to an average calcium intake of $860 \mathrm{mg}$ per day received either a calcium supplement of $1,000 \mathrm{mg}$ per day or a placebo for five years in this randomized controlled trial. A significant problem is therefore the generalizability of the results of this study. Who would prescribe such a high level of calcium to healthy women for such a lengthy period?

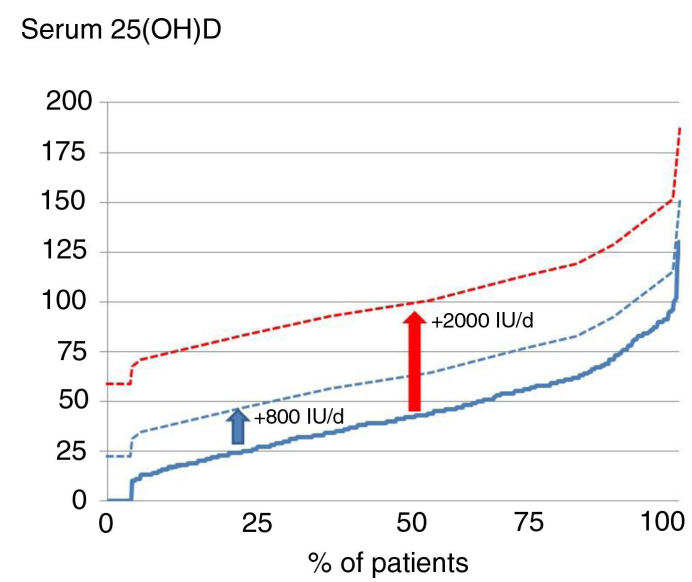

Fig. 7. 25(OH)D level achieved with use of a set dosage of vitamin D supplementation (800 IU and 2,000 IU per day). 
There was a slightly increased risk of myocardial infarction in the treated group.

The study by Lewis et al. (58) contradicts this. In this study, 1,460 women aged 70 years or older were given a calcium supplement of 1,200 mg or a placebo. In addition, these women consumed about $950 \mathrm{mg}$ calcium via the diet. In this study, the investigators found no evidence that calcium supplementation causes an increased risk of cardiovascular conditions during an average follow-up of 4.5 years.

Several large observational studies performed more than 10 years ago even show a favorable effect of calcium supplementation such as the IOWA Health Study (59) and the Nurses' Health Study (60). The observed protective effect of higher calcium intake in these studies is probably due to the phenomenon of confounding by indication: healthy women who consume more calcium, will in general have a healthier lifestyle: more exercise, healthier diet, and less smoking.

In a reanalysis of The Women's Health Initiative Study there was a slight increase in cardiovascular events in the intervention group, most noticeable in myocardial infarction (61).

In a recently published prospective (Swedish mammogram) cohort study the use of calcium supplementation was not associated with cardiovascular mortality or ischemic heart disease (62). In women who had a dietary intake of $>1,400 \mathrm{mg}$ calcium per day, the use of calcium supplements was associated with a higher all-cause mortality rate (62).

In another recently published prospective observation study an association of calcium supplementation with an increased risk of cardiovascular mortality was found in men but not in women (63).

To summarize, probably because of heterogeneity and limitations in study design, the result of the different studies are contradictory. Some show a cardio protective effect of calcium supplementation. Other studies find an increased risk of myocardial infarction, cardiac mortality, and/or total mortality (but only with a total calcium intake greatly exceeding the usual recommendations). Yet other studies find no significant relation between calcium supplementation and cardiac events. Probably only (well-designed and sufficiently powered) prospective randomized controlled trials with cardiac events as a prespecified primary end point will be able to allow definite conclusions on this subject. After an extensive literature search we have come to the conclusion that as up to now no such studies have been published.

\section{Calcium intake and drug interactions and adverse effects}

It is important to note that oral use of calcium salts can reduce the absorption of bisphosphonates, tetracyclines (doxycycline, minocycline, and demeclocycline), fluoroquinolones (ciprofloxacin, levofloxacin, norfloxacin, ofloxacin, and moxifloxacin), levothyroxine, fiberrich food, and levodopa. For these medicines, it is generally recommended to take these at least $2 \mathrm{~h}$ before ingestion of calcium salts; for the fluoroquinolones an interval of $4 \mathrm{~h}$ is preferable.

As the gastric emptying speed decreases with age and emptying takes longer in certain patients with specific conditions (for example in diabetes patients with gastroparesis due to autonomic neuropathy), it is probably better for all these medicines to maintain a period of $4 \mathrm{~h}$ between intake of these medicines and ingestion of calcium salts (longer if indicated, as in the case of gastroparesis).

Calcium could cause constipation, which can form a reason to add a laxative, for example, a magnesium salt or oxide.

\section{Patient preference}

Assuming that therapy compliance is an important subject in the treatment of osteoporosis, any preference by the patient for a certain medication is probably also important. There are very few direct comparative studies on patient preference, also for calcium tablets. Which form of administration of calcium supplementation (tablet or effervescent tablet in solution) does the patient prefer? Do patient-friendly packages combining calcium and vitamin D and bisphosphonate promote therapy compliance? Research performed in the Netherlands used a randomized, open, cross-over trial in 102 patients to compare Calci-Chew $\mathrm{D}_{3}^{\circledR}$ chewable tablets to $\mathrm{CaD}^{\circledR}$ sachets (64). It was determined before the start that patient preference would be the most important primary measure of outcome: $67 \%$ preferred the chewable tablet, $19 \%$ the sachet, and $15 \%$ had no preference (64). The question that arises is how to interpret this: there was no difference in clinical relevant factors such as tolerance, compliance, and adverse effects. Also the actual medication taken was not significantly different: of the 14 days, the chewable tablet was taken an average of 12.8 days and the sachet 13.5 days. One point of criticism on this study is the extent to which these results over a period of 14 days can be extrapolated to the long term, for example a period of 5 years. The tolerability was similar for the two formulations. The authors concluded that patient preference is very important for medication that should be used chronically but also that the design of studies and the interpretation of the data are complicated.

\section{Practical advice for calcium and vitamin D supplementation}

Based on guidelines, optimization of total calcium intake towards a total of $1,000-1,200 \mathrm{mg}$ calcium per day is considered necessary and sufficient in the context of osteoporosis and fracture prevention strategies with drug 
treatment. Calcium supplementation can be achieved by diet, mainly milk products (milk, yogurt, or cheese) or calcium-containing tablets. Dietary calcium intake is preferred and 3-4 portions of milk products per day should be advised. If this cannot be achieved, supplementation of calcium should be considered. If a patient consumes 1-2 portions of milk products per day, then the advice is to add 1-2 portions of milk products per day or $500 \mathrm{mg}$ of calcium supplementation. If a patient does not take any milk products, supplementation of $1,000 \mathrm{mg}$ calcium is needed. No adjustment is required if the patient consumes 3-4 portions of milk products per day. In the context of the concern about cardiovascular conditions, calcium supplementation should be individualized.

When considering the choice of calcium supplements one should take into account that fractional calcium absorption is $24 \%$ higher for calcium citrate compared to calcium carbonate, probably because of higher dissolution in the ileum, where $65 \%$ of the total calcium is absorbed. The effect of proton pump inhibitors on calcium absorption are inconclusive as is the case with the effect of age-related changes in gastric physiology (65). The practical advice concerning vitamin D supplementation as part of osteoporosis treatment is to prescribe a minimum dose of $800 \mathrm{IU}$ per day of vitamin $\mathrm{D}_{3}$. This also applies to people in nursing homes and care homes and patients with a recent fracture, irrespective of BMD. Higher dosages could be considered in case of severe vitamin D deficiency with secondary hyperparathyroidism.

\section{Conflict of interest and funding}

The authors have not received any funding or benefits from industry or elsewhere to conduct this study.

\section{References}

1. Albright F, Burnett CH, Parson W, Reifenstein ECJ, Roos A. Osteomalacia and late rickets; the various etiologies met in the United States with emphasis on that resulting from a specific form of renal acidosis, the therapeutic indications for each etiological sub-group, and the relationship between osteomalacia and Milkman's syndrome. Medicine 1946; 25: 399-479.

2. Mackenzie CG, Mackenzie JB, McCollum EV. The prevention by alpha-tocopherol of "Cod liver oil muscular dystrophy" in the rabbit. Science 1941; 94: 216-7.

3. CBO (2011). Richtlijn Osteoporose en fractuurpreventie, derde herziening (2011). DCHG. Available from: http://www.nvr.nl/ uploads/1F/c0/1Fc0oDLyo7H0Nnn70mdQ9w/CBO-richtlijnosteoporose-en-fractuurpreventie-2011.pdf [cited 20 February 2013].

4. Papaionnou A, Moru S, Cheung AM, Atkinson S, Brown JP, Feldman S, et al. Practical guidelines for the diagnosis and management of osteoporosis in Canada. 2010 Nov 23; 182(17): 1864-73. doi: 10.15031/cjma.100771.

5. Rosen CJ, Abrams SA, Aloia JF, Brannon PM, Clinton SK, Durazo-Arvizu RA, et al. IOM committee members respond to endocrine society vitamin D guideline. J Clin Endocrinol Metabol 2012; 97: 1146-52.
6. Moyer VA, on behalf of the U.S. Preventetive Services Task Force. Vitamin D and calcium supplementation to prevent fractures in adults: U.S. Preventive Services Task Force Recommendation Statement. Ann Intern Med 2013; 158: 691-6.

7. Tang BM, Eslick GD, Nowson C, Smith C, Bensoussan A. Use of calcium or calcium in combination with vitamin D supplementation to prevent fractures and bone loss in people aged 50 years and older: a meta-analysis. Lancet 2007; 370: 657-66.

8. Bischoff-Ferrari HA, Dawson-Hughes B, Baron JA, Burckhardt $\mathrm{P}$, Li R, Spiegelman D, et al. Calcium intake and hip fracture risk in men and women: a meta-analysis of prospective cohort studies and randomized controlled trials. Am J Clin Nutr 2007; 86: $1780-90$.

9. Boonen S, Lips P, Bouillon R, Bischoff-Ferrari HA, Vanderschueren D, Haentjens P. Need for additional calcium to reduce the risk of hip fracture with vitamin d supplementation: evidence from a comparative metaanalysis of randomized controlled trials. J Clin Endocrinol Metab 2007; 92: 1415-23.

10. Avenell A, Gillespie WJ, Gillespie LD, O'Connell D. Vitamin D and vitamin $\mathrm{D}$ analogues for preventing fractures associated with involutional and post-menopausal osteoporosis. Cochrane Database Syst Rev 2009: CD000227.

11. DIPART (Vitamin D Individual Patient Analysis of Randomized Trials) Group. Patient level pooled analysis of 68500 patients from seven major vitamin D fracture trials in US and Europe. BMJ 2010; 340: b5463.

12. Bischoff-Ferrari HA, Orav EJ, Dawson-Hughes B. Effect of cholecalciferol plus calcium on falling in ambulatory older men and women: a 3-year randomized controlled trial. Arch Intern Med 2006; 166: 424-30.

13. Chapuy MC, Arlot ME, Duboeuf F, Brun J, Crouzet B, Arnaud $\mathrm{S}$, et al. Vitamin D3 and calcium to prevent hip fractures in elderly women. N Engl J Med 1992; 327: 1637-42.

14. Bischoff-Ferrari HA, Willett WC, Wong JB, Stuck AE, Staehelin HB, Orav EJ, et al. Prevention of nonvertebral fractures with oral vitamin D and dose dependency: a metaanalysis of randomized controlled trials. Arch Intern Med 2009; 169: 551-61.

15. Prince RL, Austin N, Devine A, Dick IM, Bruce D, Zhu K. Effects of ergocalciferol added to calcium on the risk of falls in elderly high-risk women. Arch Intern Med 2008; 168: 103-8.

16. Coburn JW, Hartenbower DL, Massry SG. Intestinal absorption of calcium and the effect of renal insufficiency. Kidney Int 1973; 4: 96-104

17. Coburn JW, Koppel MH, Brickman AS, Massry SG. Study of intestinal absorption of calcium in patients with renal failure. Kidney Int 1973; 3: 264-72.

18. McCormick CC. Passive diffusion does not play a major role in the absorption of dietary calcium in normal adults. J Nutr 2002; 132: $3428-30$.

19. Fleet JC, Schoch RD. Molecular mechanisms for regulation of intestinal calcium absorption by vitamin $\mathrm{D}$ and other factors. Crit Rev Clin Lab Sci 2010; 47: 181-95.

20. Heaney RP. Vitamin D and calcium interactions: functional outcomes. Am J Clin Nutr 2008; 88: 541S-4S.

21. Perez AV, Picotto G, Carpentieri AR, Rivoira MA, Peralta Lopez ME, Tolosa de Talamoni NG. Minireview on regulation of intestinal calcium absorption. Emphasis on molecular mechanisms of transcellular pathway. Digestion 2008; 77: 22-34.

22. Fallingborg J. Intraluminal $\mathrm{pH}$ of the human gastrointestinal tract. Dan Med Bull 1999; 46: 183-96.

23. Luria T, Matsliah Y, Adir Y, Josephy N, Moran DS, Evans RK, et al. Effects of a prolonged submersion on bone strength and metabolism in young healthy submariners. Calcif Tissue Int 2010; 86: 8-13. 
24. Bronner F. Mechanisms and functional aspects of intestinal calcium absorption. J Exp Zool A Comp Exp Biol 2003; 300: $47-52$.

25. Bronner F. Mechanisms of intestinal calcium absorption. J Cell Biochem 2003; 88: 387-93.

26. Evans DF, Pye G, Bramley R, Clark AG, Dyson TJ, Hardcastle JD. Measurement of gastrointestinal $\mathrm{pH}$ profiles in normal ambulant human subjects. Gut 1988; 29: 1035-41.

27. Goss S, Prushko J, Bogner R. Factors affecting calcium precipitation during neutralisation in a simulated intestinal environment. J Pharm Sci 2010; 99: 4183-91.

28. Goss S, Rafferty P, Prushko J, Gorman E, Taub M, Bogner R. Exploration of intestinal calcium precipitation as a barrier to absorption at high calcium doses. Pharm Res 2008; 25: 2760-8.

29. Goss SL, Lemons KA, Kerstetter JE, Bogner RH. Determination of calcium salt solubility with changes in $\mathrm{pH}$ and $\mathrm{P}(\mathrm{CO}(2))$, simulating varying gastrointestinal environments. J Pharm Pharmacol 2007; 59: 1485-92.

30. Quesada Gomez JM, Blanch Rubio J, Diaz Curiel M, Diez Perez A. Calcium citrate and vitamin D in the treatment of osteoporosis. Clin Drug Investig 2011; 31: 285-98.

31. Sakhaee K, Bhuket T, Adams-Huet B, Rao DS. Meta-analysis of calcium bioavailability: a comparison of calcium citrate with calcium carbonate. Am J Ther 1999; 6: 313-21.

32. Micheletti MC, Zartarian M. Comparison of calcium retention measured using a radionuclide method after administration of $1000 \mathrm{mg}$ elemental calcium in two different galenic forms, in one or two doses. Rev Rhum Engl Ed 1996; 63: 51-5.

33. Heller HJ, Stewart A, Haynes S, Pak CY. Pharmacokinetics of calcium absorption from two commercial calcium supplements. J Clin Pharmacol 1999; 39: 1151-4.

34. Heller HJ, Greer LG, Haynes SD, Poindexter JR, Pak CY. Pharmacokinetic and pharmacodynamic comparison of two calcium supplements in postmenopausal women. J Clin Pharmacol 2000; 40: 1237-44.

35. Heaney RP, Dowell MS, Bierman J, Hale CA, Bendich A. Absorbability and cost effectiveness in calcium supplementation. J Am Coll Nutr 2001; 20: 239-46.

36. Kenny AM, Prestwood KM, Biskup B, Robbins B, Zayas E, Kleppinger A, et al. Comparison of the effects of calcium loading with calcium citrate or calcium carbonate on bone turnover in postmenopausal women. Osteoporos Int 2004; 15: $290-4$.

37. Hanzlik RP, Fowler SC, Eells JT. Absorption and elimination of formate following oral administration of calcium formate in female human subjects. Drug Metab Dispos 2005; 33: 282-6.

38. Thomas SD, Need AG, Tucker G, Slobodian P, O'Loughlin PD, Nordin BE. Suppression of parathyroid hormone and bone resorption by calcium carbonate and calcium citrate in postmenopausal women. Calcif Tissue Int 2008; 83: 81-4.

39. Karp HJ, Ketola ME, Lamberg-Allardt CJ. Acute effects of calcium carbonate, calcium citrate and potassium citrate on markers of calcium and bone metabolism in young women. Br J Nutr 2009; 102: 1341-7.

40. Hurwitz A, Brady DA, Schaal SE, Samloff IM, Dedon J, Ruhl CE. Gastric acidity in older adults. JAMA 1997; 278: 659-62.

41. Wright MJ, Proctor DD, Insogna KL, Kerstetter JE. Proton pump-inhibiting drugs, calcium homeostasis, and bone health. Nutr Rev 2008; 66: 103-8.

42. Wright MJ, Sullivan RR, Gaffney-Stomberg E, Caseria DM, O'Brien KO, Proctor DD, et al. Inhibiting gastric acid production does not affect intestinal calcium absorption in young, healthy individuals: a randomized, crossover, controlled clinical trial. J Bone Miner Res 2010; 25: 2205-11.

43. Khalili H, Huang ES, Jacobson BC, Camargo CA, Jr., Feskanich D, Chan AT. Use of proton pump inhibitors and risk of hip fracture in relation to dietary and lifestyle factors: a prospective cohort study. BMJ 2012; 344: e372.

44. Bates CJ, Prentice A, van der Pols JC, Walmsley C, Pentieva KD, Finch S, et al. Estimation of the use of dietary supplements in the National Diet and Nutrition Survey: people aged 65 years and Over. An observed paradox and a recommendation. Eur $\mathbf{J}$ Clin Nutr 1998; 52: 917-23.

45. Volkert D, Kreuel K, Heseker H, Stehle P. Energy and nutrient intake of young-old, old-old and very-old elderly in Germany. Eur J Clin Nutr 2004; 58: 1190-200.

46. Chapuy MC, Chapuy P, Thomas JL, Hazard MC, Meunier PJ. Biochemical effects of calcium and vitamin D supplementation in elderly, institutionalized, vitamin D-deficient patients. Rev Rhum Engl Ed 1996; 63: 135-40.

47. Elders PJ, Lips P, Netelenbos JC, van Ginkel FC, Khoe E, van der Vijgh WJ, et al. Long-term effect of calcium supplementation on bone loss in perimenopausal women. J Bone Miner Res 1994; 9: 963-70.

48. van Beresteijn EC, van’t Hof MA, Schaafsma G, de Waard H, Duursma SA. Habitual dietary calcium intake and cortical bone loss in perimenopausal women: a longitudinal study. Calcif Tissue Int 1990; 47: 338-44.

49. Ooms ME, Lips P, Roos JC, van der Vijgh WJ, Popp-Snijders C, Bezemer PD, et al. Vitamin D status and sex hormone binding globulin: determinants of bone turnover and bone mineral density in elderly women. J Bone Miner Res 1995; 10: 1177-84.

50. van den Bergh JP, Shab Bidar S, Bours S, van Geel ACM, Geusens PP. Need of calcium and vitamin D in patients after a recent fracture. Food Nutr Sci 2012; 3: 539-47.

51. Bours SP, van Geel TA, Geusens PP, Janssen MJ, Janzing HM, Hoffland GA, et al. Contributors to secondary osteoporosis and metabolic bone diseases in patients presenting with a clinical fracture. J Clin Endocrinol Metab 2011; 96: 1360-7.

52. Dawson-Hughes B, Mithal A, Bonjour JP, Boonen S, Burckhardt P, Fuleihan GE, et al. IOF position statement: vitamin $\mathrm{D}$ recommendations for older adults. Osteoporos Int 2010; 21: 1151-4.

53. Cranney A, Horsley T, O’Donnell S, Weiler H, Puil L, Ooi D, et al. Effectiveness and safety of vitamin D in relation to bone health. Evid Rep Technol Assess (Full Rep) 2007; 158: $1-235$.

54. Heaney RP. The vitamin D requirement in health and disease. J Steroid Biochem Mol Biol 2005; 97: 13-19.

55. van den Bergh JP, Bours SP, van Geel TA, Geusens PP. Optimal use of vitamin D when treating osteoporosis. Curr Osteoporos Rep 2011; 9: 36-42.

56. Gallagher JC, Sai A, Templin T, 2nd, Smith L. Dose response to vitamin $\mathrm{D}$ supplementation in postmenopausal women: a randomized trial. Ann Intern Med 2012; 156: 425-37.

57. Bolland MJ, Barber PA, Doughty RN, Mason B, Horne A, Ames R, et al. Vascular events in healthy older women receiving calcium supplementation: randomized controlled trial. BMJ 2008; 336: 262-6.

58. Lewis JR, Calver J, Zhu K, Flicker L, Prince RL. Calcium supplementation and the risks of atherosclerotic vascular disease in older women: results of a 5 -year RCT and a 4.5 -year follow-up. J Bone Miner Res 2011; 26: 35-41.

59. Bostick RM, Kushi LH, Wu Y, Meyer KA, Sellers TA, Folsom AR. Relation of calcium, vitamin D, and dairy food intake to ischemic heart disease mortality among postmenopausal women. Am J Epidemiol 1999; 149: 151-61. 
60. Iso H, Stampfer MJ, Manson JE, Rexrode K, Hennekens CH, Colditz GA, et al. Prospective study of calcium, potassium, and magnesium intake and risk of stroke in women. Stroke 1999; 30: 1772-9.

61. Bolland MJ, Grey A, Anenell A, Gamble GD, Reid IR. Calcium supplements with or without vitamin D and risk of cardiovascular events: reanalysis of the Women's Health Initiative limited access dataset and meta-analysis. Br Med J 2011; 342: d2040.

62. Michaëlsson K, Melhus H, Warensjö E, Wolk A, Byberg L. Long term calcium intake and rates of all cause and cardiovascular mortality: community based prospective longitudinal cohort study. Br Med J 2013; 346: f228. doi: 10.1136/bmj.228.

63. Xiao Q, Murphy RA, Houston DK, Harris TB, Chow W-H, Park Y. Dietary and supplemental calcium intake and cardiovascular disease mortality. JAMA Intern Med 2013; 173: 639-46. doi: 10.1001/jamainternmed.2013.3283.
64. den Uyl D, Geusens PP, van Berkum FN, Houben HH, Jebbink MC, Lems WF. Patient preference and acceptability of calcium plus vitamin D3 supplementation: a randomized, open, crossover trial. Clin Rheumatol 2010; 29: 465-72.

65. Newton JL. Effect of age-related changes in gastric physiology on tolerability of medications for older people. Drugs Aging 2005; 22: 655-61.

*Robert Y. van der Velde

Department of Internal Medicine

VieCuri Medical Centre for North Limburg

Venloseweg 210

5912 BL, Venlo, The Netherlands

Email: rvdvelde@viecuri.nl 